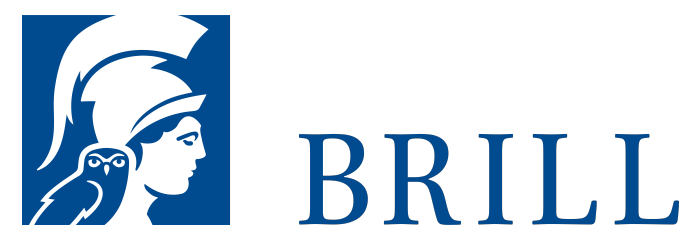

\title{
Poetische Dogmatik: Christologie
}

4 BÃandige Sonderausgabe. Namen_!_Schrift und Gesicht _! Leib und Leben_!_Figuren

Authors: Ursula Stock and Alex Stock

'Stock gelingt mit seiner â€žPoetischen Dogmatikâ€o ein kleines Wunder. Er f̃̃ $1 / 4$ hrt Theologie als eine festliche, ja heitere Disziplin vor. Obwohl die dunklen Seiten der Kirchengeschichte nicht ausgeblendet werden, lÃqÃ Ÿt er SchÃatze einer reichen Tradition funklen. So entsteht das Bild einer zerklÃ̄1/4fteten, dennoch idealistischen Kultur-Landschaft, die mit kaum gebrochener Ausstahlungskraft bis heute besteht.' Chr. Schuler in: FAZ 'Da Alex Stock, al quale bisognerÃ essere molti grati per lâ $€^{\text {tw }}$ auda cia con cui ha concepito il progetto, lâ $€^{\text {mw }}$ acribia con cui lâ $€^{\mathrm{m}}$ 'ha attuato e la richezza dei contenuti, inediti nella tradizione dogmatica, che ha messo a nostra disposizione, attendiamo.' S. Dianich in: Vivens homo (Florenz 2001)

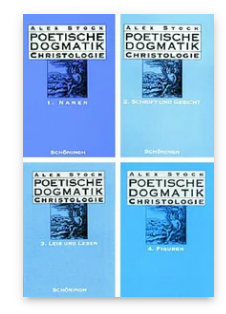

Pages: 1456

Seiten

Language:

German

Subjects:

General,

Theology and

World

Christianity

Publisher: Brill |

SchÃ ๆningh

Series:

Poetische

Dogmatik:

Christologie,

Volume: 1-4

E-Book (PDF)

Released online:

O3 Feb 2020

ISBN: 978-3-

657-76890-5

List price

USD Â $\$ 324.00$

Hardback

Publication date:

og Dec 2009

ISBN: 978-3-

506-7689o-2

List price

USD Â $\$ 324.00$ 
For more information see brill.com

Order information: Order online at brill.com +44330 333 0049 | customerservices@brill.com Submission information: brill.com/authors

Titles published by Brill | Fink, Brill | mentis or Brill | Schöningh: +49(o)715413279216| brill@brocom.de 